\title{
Зондаж богоносца
}

ЮДИН Г. Б. (2020). ОБЩЕСТВЕННОЕ МНЕНИЕ, ИЛИ ВЛАСТЬ ЦИФР. СПБ.: ЕУ СПБ. 174 С. ISBN 978-594380-294-2

\author{
Артемий Магун \\ Профессор, Европейский университет в Санкт-Петербурге, \\ директор Центра практической философии «Стасис», главный редактор журнала «Стасис» \\ Адрес: Гагаринская ул., д. 6/1, литера А, Санкт-Петербург, Российская Федерация 191187 \\ E-mail: amagun@eu.spb.ru
}

\begin{abstract}
Статья является одновременно развернутой рецензией на книгу Г. Б. Юдина «Общественное мнение, или Власть цифр» и рассуждением о самом феномене общественного мнения в контексте репрессивных тенденций современного общества, с позиций критической теории. С опорой на Т. Адорно, автор показывает, что опросы общественного мнения являются не только результатом отчуждающего овеществления, но и исходного субъективизма, который превращает отношения субъекта с обществом в отстраненную, созерцающую и судящую установку. Субъективация сочетается, таким образом, с объективацией. В соответствии с тезисом Юдина показывается, что социальная наука, если она не хочет быть инструментом бюрократического господства, должна опираться на диалектическую логику.
\end{abstract}

Ключевые слова: общественное мнение, Левада-Центр, критическая теория, диалектика в социологии, Г. Б. Юдин, квантификация, овеществление

\section{Критика теории и практики «общественного мнения»}

Книга Г. Юдина «Общественное мнение, или Власть цифр», вышедшая в серии Европейского университета «Азбука понятий», представляет собой, в соответствии с концепцией серии, историю понятия «общественное мнение» (строго говоря, «публичное мнение», public opinion). Рассказывается в ней не только о значении термина, но и о самом феномене, к которому тот относится: в частности, о технологиях исследования общественного мнения, о прецедентах его удачных и неудачных оценок. Но кроме того, книга содержит еще и острую политическую полемику против... видимо, как раз общественного же мнения, особенно российского, которое ошибочно полагает опросы общественного мнения чем-то прогрессивным, современным и полезным для демократического общества. На самом же деле, хотя эти опросы возникли и широко практикуются в США, это не означает их прогрессивности и демократичности. То есть, безусловно, пишет Юдин, что опросы соответствуют процедуре всеобщих, индивидуальных и тайных выборов и таких же референдумов (по сути, опросы это и есть, по замыслу Гэллапа, «перманентные референдумы» (с. 130-133)). Но выборы и референдумы, вопреки доксе, не являются на самом деле ядром демократического режима, а, наоборот, представляют 
собой относительно авторитарный аспект либеральных демократий: Юдин называет его «плебисцитарным», в том смысле, что начальники (поочередно) правят и периодически спрашивают народ, все ли в порядке.

Поэтому подчеркнутая опора властей «на опросы общественного мнения не только не способствует, но и прямо противоречит подлинным формам демократического правления - дебатам, дискуссиям, коллективному самоуправлению, демонстрациям, революциям и вообще любым видам организованного коллективного действия» (с. 22).

Тому есть несколько причин.

Во-первых, люди опрашиваются индивидуально, а учитываются глобально, в результате чего фабрикуется достоверность некоего объективно существующего, но невидимого монстра («Общество», «Публика», «Народ»), в котором я участвую, но с которым ничего нельзя поделать. Опросы предполагают образ общества как агрегата индивидов, игнорируя его разнородность, не учитывая тех коммуникативных механизмов, которые цементируют общество. Юдин разделяет «буржуазную» концепцию общественного мнения, где последнее возникает в результате дискуссий - она была характерна для XIX века, - и «демократическую» концепцию, где никто ничего не обсуждает, и суммирование идет индивидуально - это как раз та концепция, что воплотилась в опросах общественного мнения в духе Гэллапа.

Во-вторых, предполагается, что у людей уже есть мнения по задаваемым вопросам, и опрос заставляет индивида искусственно определиться в неопределенной ситуации, фиксирует, пригвождает к месту его, возможно, случайное настроение, создает проблему и проблематизацию там, где они не были осознаны или отсутствовали вовсе. Все это наделяет тех, кто задает вопросы, огромной властью, которой, конечно, обладают не лично социологи, но в целом политическо-экспертный класс.

В-третьих, в отличие от выборов, опросы не затрагивают всех, опрашиваются лишь немногие, что опять же предполагает объективную природу мнения, бессознательно живущего в тебе как представителе некой социальной группы, и лишает тебя, при учете твоего «мнения», какого-либо участия в его выработке: это выборы минус участие в выборах, сумма предпочтений, не требующая от гражданина минимально ответственного поступка.

В Америке опросы, не только политические, обладают тем негативным эффектом, что предъявляют политическую позицию или потребительский выбор в мнимо объективной форме, как кивок на других: например, «12\% американцев считают, что надо запретить атомную энергию», или «50\% американцев считают, что Трамп продался русским», вместо того, чтобы автор просто выразил и объяснил свое собственное мнение. Подобная мифология цифр потенциально ведет к безответственности и сокрытию субъектных установок в оценке реальности.

Но пафос Юдина направлен в большей степени не на США, хотя они и распространили первыми столь опасную практику, а на родину автора и читателя. 
Именно в путинской России опросы общественного мнения, столь недавно реабилитированные и ранее с энтузиазмом распространяемые прогрессивными интеллектуалами критического толка (а не конформистами вроде Гэллапа), встали на службу политической власти откровенно авторитарного типа. Здесь, как показывает Юдин, опросы не дублируют или предсказывают выборы, как в США, а попросту, во многих случаях, заменяют их. И поскольку российское общество действительно расколото по отношению к поддержке правящего режима, опросы являются, помимо прочего, гениальным способом заткнуть рот критикам властей (в основном городскому образованному классу): им постоянно напоминают, что они в количественном меньшинстве и что большинство стоит на консервативно-реакционных позициях (обычно довольно близко к тексту воспроизводя по всем вопросам точки зрения телеведущих центральных каналов ТВ). Губернаторы в России смещаются и даже войны начинаются или не начинаются в зависимости от опросов, то есть не от воли народа, а от его гипостазированного «мнения».

Лидеры российского государства, отнюдь не будучи по своим убеждениям демократами, берут на вооружение элементы современного функционирования демократии на Западе - выборы и опросы. Хотя выборы выхолащиваются (в отсутствие значимой конкуренции) и формализуются - тем не менее как ритуальная форма и механизм минимального вовлечения граждан в легитимацию режима они важны. А вот опросы, то есть по идее механизм предвосхищения и эмуляции выборов, как раз используются на полном серьезе, содержательно, а не формально, и для этого поддерживается диверсификация опросных фирм, от консервативного (по установкам исследователей) опросного центра ФСО до праволиберального Левада-Центра. Все это вместе обеспечивает и плебисцитарность, и научно-технологическую рациональность режима, не теряющего тем самым «концерта» между властью и народом (если, конечно, оба наши «концерта», выборы и опросы, нормально работают).

Юдин отмечает, что опросы играют социально-конструктивную роль, то есть сами формируют то мнение, которое претендуют «измерять» (с. 20-21). Но тут следует дальше обсудить, к чему этот процесс содержательно ведет в России и в подобных незападных странах.

\section{Случай Левада-Центра}

В России, как и во многих других странах, опросы зачастую выявляют раскол населения на «прогрессивное» и «отсталое», в противовес ранее принятому делению общества на классы и партии. Квантификация позволяет и на Западе объяснять электоральные поражения системных либеральных партий «популизмом». Но в России опросы, тесно связанные с идеологическим процессом, особенно ярко высвечивают проблему «непросвещенного народа».

Например, в недавнем исследовании Левада-Центра выясняется, что часть населения считает российский режим движением к «авторитарной диктатуре», дру- 
гая - большая часть - видит в нем развитие демократии, а еще одна группа испугана ростом анархии (Гудков, 2020). Зная примерно установки исследователей, мы понимаем, почему они предложили опрашиваемым именно эти варианты: они представляют соответственно прогрессистское и консервативное крыло общества.

В России опросная наука приобрела интересное содержательное наполнение гипертрофированное продолжение тех же самых тенденций. Ю. Левада, Л. Гудков и Б. Дубин, социальные теоретики 1970-80-х годов, работавшие во многом неформально, даже подпольно, и не допущенные в СССР к проведению опросов, создали в перестройку ведущий российский центр по исследованию общественного мнения. С самого начала они не только демонстрировали высочайший уровень методологического профессионализма, но в то же время проверяли и подтверждали в этих исследованиях свою научную теорию, сформулированную в духе когдато популярных на Западе «теорий массового общества». Наряду с этой критически ориентированной теорией авторы своеобразно использовали и гораздо более аффирмативную теорию Парсонса ${ }^{1}$. По Леваде и его соавторам, получалось, что «советский человек», то есть типичный и наиболее распространенный представитель населения, это внутренне отсталое и агрессивное существо, безнадежно испорченное вредной левой политикой СССР. Это якобы устойчивая диспозиция, реформировать ее сложно. Особый акцент при этом ставится на «простоте» и «массовидности» (Левада, 1993: 24) советского и постсоветского человека, что показывает, что речь идет об очередном столкновении просвещенной публики с народом. Когда на выборах стали побеждать консервативные партии с националистическими лозунгами, теория Левада-Центра оказалась эмпирически подтвержденной, и не перестает подтверждаться по сей день. Измеряешь, тестируешь «общественное мнение», «публичность», а вместо них получаешь темный, но несущий (неприятную) истину, народ. Выходит, такое народничество с обратным знаком. Вообще-то такой научный пафос и даже методологический активизм не очень типичны для полстеров - скорее, это яркое и неоднозначное явление именно российской идеологической жизни. Юдин не останавливается на этом интересном случае в самой книге, по-видимому, в порядке самоцензуры (а жаль), но высказывается по ней в других публикациях.

Так, например, в блоге на сайте «Эха Москвы» он в 2019 году писал:

Проблема, на самом деле, не в методологии, а в идеологии. Левада-Центр не может не видеть этих возражений - там работают квалифицированные коллеги, которые прекрасно понимают, что вопрос надо просто выкинуть.

1. О Левада-Центре и истоках его мышления см. подробнее недавнюю статью Гульназ Шарафутдиновой, где она, в частности, указывает на исследования тоталитарной личности в США в 1940-1950-х годах, а также на теорию систем Парсонса, в соответствии с которой психология советского человека должна была быть направлена на поддержание советского же режима (Sharafutdinova, 2019: 180). Впрочем, внимательное чтение «Советского простого человека» говорит о совсем другом применении Парсонса: советское общество противопоставляется, в критическом смысле, функционально интегрированному западному. 
Однако они не могут справиться с желанием провести со своими респондентами «тест Сталина», чтобы вывести на свет их тоталитарную сущность, обнаружить жуткий Народ-Сталин. Потому что в «ЛЦ» смотрят на мир через призму довольно странной и противоречивой схемы «человека советского». Смысл этой схемы, грубо говоря, в том, что в России был, есть и будет тоталитаризм, ничего другого тут быть не может, за исключением коротких перерывов. Эта схема плоха тем, что пользуется теми представлениями о стране, которые выработало поколение Юрия Левады, и накладывает их на совершенно иные исторические обстоятельства. Она живет прошлым и не дает в упор заметить, что мы живем в совершенно другом политическом режиме, с совершенно другими проблемами и вызовами - хотя для этого достаточно выглянуть в окно. Неудивительно, что поколение диссидентов инстинктивно выбирает тот способ отношения к государству, который помогал ему выжить полвека назад. Удивительно, что это удается выдавать за «социологию». (Юдин, 2019)

И у Левада-Центра, и в других российских исследованиях общественного мнения имеет место порочный круг положительной обратной связи: публикация результатов усиливает те тенденции, о которых идет речь, элиты оправдывают идиотизм телевизионных передач ссылкой на дикость народа, и народ еще больше «дичает». Очевидно, что большую роль здесь играет и абсолютизированный капитализм, приведший к коммерциализации средств массовой информации.

Эмпирически результаты Левада-Центра достаточно объективны и репрезентативны, как правило, верно предсказывают результаты выборов и т. д. Их вопросы при этом зачастую провокативны («Считаете ли Вы, что феминисток нужно подвергать смертной казни?», «Как Вы думаете, оправданны ли человеческие жертвы, которые понес советский народ в сталинскую эпоху, великими целями и результатами, которые были достигнуты в кратчайший срок?» и т. п.). Такие вопросы не всегда отвечают стандартам объективной социальной науки, но в более общем плане они как раз являются интересным новшеством: полстеры ЛевадаЦентра, по собственному признанию, проводят такими вопросами своеобразные эксперименты, стараются выявить своеобразную «зону ближайшего развития» масс. Но в отличие от Л. Выготского (Выготский, 1984), который понимал под этим понятием самореализацию субъекта, левадовцы зондируют, готов ли субъект к полной деградации и моральному апокалипсису ${ }^{2}$.

Проблема данного типа социологии не в том, что она неверно отражает действительность - она ее отражает, и даже с критическим опережением - но в том, что их система вопросов обусловлена взглядом либерального интеллигента на народ и что она конституирует свой предмет по контрасту с собой. Потому что оптика интеллигентного полстера (заложенная в сам инструмент, с его встроенным субъективизмом: вменением людям свободно формируемых рациональных «мнений» по всем вопросам) находит в своем материале не то, что искала, а скорее

2. Л. Гудков: «Мы в ситуации, которая больше всего напоминает Германию перед приходом Гитлера»; «Весьма вероятно, возможна полная деградация страны» (Велехов, Гудков, 2016). 
опровержение того, что искала. Так же как приборы фиксируют сопротивление себе в твердых объектах, так же как ядерная физика приводит к постройке атомной бомбы, основанной на нарушающей границы атомов ядерной реакции. Вот так и получается, что просвещенная наука плодит, в социальном своем приложении, дикость, и сама становится, вопреки себе, идеологией варварства (авторитарного правления).

\section{Общественное мнение в контексте идеологии позднего модерна}

Вернемся, однако, к книге Юдина. В чем ее общетеоретический посыл? Он не до конца ясен, но, по-видимому, заключается в критике опросов общественного мнения как не только и не столько научного, а скорее политического института, который конструирует реальность вместо того, чтобы ее описывать (подобно и естественным наукам, в понимании Б. Латура).

Возникновение современного общественного мнения тесно связано с появлением исследований общественного мнения. Это может показаться странным, ведь мы привыкли думать, что объект исследования существует независимо от того, изучаем мы его или нет: задача науки состоит в том, чтобы «открыть» некий новый предмет и его закономерности. Однако природа научного знания не так проста, как кажется. Современные исследователи науки и технологий (STS) сходятся в том, что говорить о существовании какого-либо научного объекта можно лишь тогда, когда он «изобретен», то есть определен и описан наукой. Некоторые из таких объектов могут появляться и исчезать вместе с эволюцией науки. Точно так же дело обстоит и с общественным мнением. Хотя это понятие существовало до современных опросов, появление исследований общественного мнения полностью изменило представления о том, чем оно является. Поскольку опросы прочно вошли в повседневную жизнь рядовых членов общества, вместе с исследованиями общественного мнения около восьмидесяти лет назад возникло и совершенно новое «общественное мнение». (С. 20-21)

За «общественным мнением» стоит плебисцитарная политическая власть, и именно отношения власти и остаются последним термином (terminus ad quem) в данной дискуссии. «Власть цифр» заключается в том, что за наукообразной риторикой кроется пропаганда. «Цифры обладают для нас совершенно особой магией. В рекламе достаточно заявить, что «8о\% докторов рекомендуют» или «что-то становится на 65\% чище», и аудитория склонна воспринимать эти цифры как удостоверенные авторитетом науки факты - хотя за ними порой может практически ничего не стоять» (с. 139).

Риторическая роль арифметики в публичной дискуссии подмечена совершенно верно. В то же время как политический теоретик я использую замечательную книгу Юдина, чтобы поставить более широкий вопрос о причинах и глобально-историческом контексте, в котором возникает вот этот плебисцитарно-социологиче- 
ский режим власти. У Юдина порой утверждается, что вся наука устроена так же, как опросная «социология» (как в выше приведенной цитате), но иногда проскакивает мысль, что опросы - это какая-то псевдонаука или недонаука, и поэтому ее данные на самом деле необъективны. Потому он столь настойчиво утверждает ${ }^{3}$, что опросы общественного мнения - это не социология, что социология к ним не имеет отношения и что «социологами» полстеров называют лишь в нашей стране, тем самым придавая ореол научности дисциплине скорее прикладной, технологичной и медийной (так же как «психологами» называют психотерапевтов, «политологами» политических комментаторов в СМИ и т. д.). И тут трудно спорить.

Но в то же время возникновение и триумф опросов есть квантификация общественного мнения, наукообразная объективация человеческой воли и гипостазирование народа (публики) в качестве потусторонней вещи-в-себе. Все это вместе есть, во-первых, феномен гегемонии позитивной науки картезианского образца, а во-вторых, феномен реификации, происходящий из логики капиталистических отношений. Оба этих феномена подробно описаны в социальной теории Франкфуртской школы (критической теории), и именно эта теория как нельзя лучше подходит для осмысления феномена, которому посвящена книга Юдина. В ней эта теория не упоминается, но это, безусловно, связано с ее жанром, который и не предполагает макротеоретических и историософских построений. Хорошо, что есть жанр рецензии.

Резюмирую вкратце, о чем идет речь.

Начиная с XVII века (Ф. Бэкон, Р. Декарт и т. д.) европейская наука формирует особое, объективирующее отношение к действительности. Предметы превращаются в мертвые, инертные вещи, лишенные качеств в пользу количеств, подчиняющиеся только слепым действующим причинам, вовлеченные в механические взаимодействия, которые можно потом использовать в технических приспособлениях.

Это отношение к действительности постепенно переходит с предметов вообще на людей. Рационализация авторитарной власти началась сразу тогда же в XVII веке (полиция, камералистика, количественные методы в учете населения, экономическая калькуляция), но достигла пика к XX веку, когда статистика легла в основу и госуправления, и даже публичной дискуссии. Возникают новые наукообразные идеологии, основанные не на открыто защищаемых политических позициях, а на якобы объективных законах истории и экономики. Это, казалось бы, должно привести к карикатурному «тоталитаризму» государств-машин, по типу «Метрополиса» Ланга, но в реальности развитие было диалектическим, и наряду с объективизацией общественных отношений в этот же период шла культивация свободной субъективности на индивидуальном уровне, как бы параллельно количественному учету (демократия, права человека, психоанализ).

3. Одна из главок даже так и называется «Социология против общественного мнения» (c. 107). 
Маркс, который обратил внимание на фетишизм буржуазного сознания и превращение человеческих отношений в отношения вещей, мыслил диалектически, но не оставил нам последовательной критики сциентизма, а его соавтор Энгельс и другие даже увлеклись им. Вебер, со своей стороны, убедительно критиковал абстрактную рациональность, но не провел диалектического анализа ее объективньхх предпосылок. Только Д. Лукач всерьез разобрался, о чем идет речь, заложив основы критической теории, самой критической из теорий ХХ века.

С точки зрения Лукача, победа абстрактной рациональности над обществом есть следствие буржуазного (капиталистического) способа производства, при котором сама рабочая сила используется как товар, а человеческое действие - овеществляется. «Овеществление» предметов в сознании есть тогда функциональный эффект коммодификации труда, превращения его в товар. Все становится «товаром» в буржуазном сознании. И сциентизм, с его объективацией социальных фактов, есть идеология, обслуживающая и воспроизводящая эту товарную оптику.

Превращение всех предметов в товары, их квантификация и низведение до фетишистских меновых стоимостей есть не только интенсивный процесс, который оказывает воздействие в этом направлении на любую форму предметности жизни (как мы смогли показать это применительно к проблеме рабочего времени), но одновременно и неотделимым отсюда образом является распространением этих форм на целостность общественного бытия. Для капиталиста эта сторона процесса равносильна усилению количественности в объектах его калькуляции и спекуляции. (Лукач, 2003: 255)

Вслед за Лукачем эту аргументацию об овеществлении развивали и повторяли представители Франкфуртской школы, во многом отходя от лукачевского марксизма. Так, Адорно и Хоркхаймер не нуждались в структурной критике науки, поскольку выдвигали аргумент от истории, более ницшеанский, нежели марксистский: стремление субъекта доминировать над природой обратилось в какой-то момент против самого субъекта, он сам стал объектом доминирования (доигрался!), жертвой собственного мифа. Этим объясняется, считали Адорно и Хоркхаймер, успех нацизма с его тотальным подчинением общества.

Овеществление означает у Лукача и Франкфуртской школы одновременно два разных эффекта. С одной стороны, социальные феномены, например, ценности, интересы, эмоции людей превращаются в инертные вещи, и им (а не «совокупностям общественных отношений») приписываются их свойства. С другой - овеществляются абстрактные тенденции, не имеющие видимого воплощения, например, нация, экономические законы, «Европа» и т.д.: сама деятельность человека предстает ему неузнанной как независимая от него. Неудивительно, что в современном английском преобладает это второе значение: оно постепенно объединилось с номиналистическим настроем английской культуры и зачастую служит для опровержения философского взгляда на вещи. Герберт Маркузе, критиковавший овеществление под именем «одномерности», привязки предмета к наличному его 
существованию, как раз защищал абстрактные понятия, универсалии от позитивистской критики: эти абстракции помещают объект в ценностный горизонт будущего (Маркузе, 1994). Поэтому разговор о реификации в этом втором значении имеет смысл, только если одновременно применяется первое значение. Так, общественное мнение выступает как автономное объективное явление только при условии отчуждения, переживаемого индивидом: изоляция и подсчет людей в качестве индивидов с их «мнениями» (овеществление 1) делает возможным существование фантомных сущностей вроде «общественного мнения» или "народа», познать которые можно только внешним, количественным образом (овеществление 2). Заметим, что овеществление 2 это не просто ошибка и что реальность всеобщих понятий («добро», «народ» и т.д.) - следствие отсутствия общности людей в реальной жизни. Всеобщие понятия полезны и как симптом отчуждения, и как полагание некоего идеала.

Ни у Лукача, ни у Адорно с Хоркхаймером аргументация не сводится к овеществлению и опредмечиванию. Есть, как я уже отметил, параллельный процесс, при котором, наоборот, каждый субъект превозносится, отчуждение его в механическом труде критикуется, и более того, общество развитого капитализма предъявляет себя как результат демократического выбора и вообще «свободное общество», в сугубо субъективно-произвольном смысле «свободы». Но спецификой такой субъективности является, говорит Лукач, «созерцательное» отношение субъекта к действительности (даже там, где он в чем-то участвует, он делает это из отстраненной позиции). «Квантификация есть овеществляющая и овеществленная оболочка, которая покрывает собой истинную сущность объектов; вообще она может иметь значимость объективной формы предметности лишь постольку, поскольку субъект, который находится в контемплятивном или (мнимо) практическом отношении к предмету, не заинтересован в сущности этого предмета» (Лукач, 2003: 252).

Ту же линию мощно продолжают Адорно и Хоркхаймер, которые показывают (Адорно, Хоркхаймер, 1997), как объективизм для граждан происходит из субъективизма деспота, и в известной степени граждане, будучи совершенно угнетены, все равно отождествляют себя именно с деспотом, занимают деспотическую позицию по отношению к природе. Действительно, современный человек старается выгородить себе маленький деспотический мирок (отношения с домочадцами или домашними животными), даже будучи подчинен во всех других отношениях.

Второе и третье поколения Франкфуртской школы, в лице Ю. Хабермаса и А. Хоннета, решительно продолжили критику сциентизма в общественной мысли. У Хабермаса эта критика вылилась в тезис о колонизации жизненного мира и технологизации публичной сферы, а Хоннет даже написал специальную книгу «Овеществление» (Honneth, 2012), где описал его разрушительное воздействие на взаимное признание людей в качестве свободных деятельных личностей. Нетрудно, однако, увидеть, что у этих более поздних авторов на второй план уходит именно критика субъективизма буржуазного общества, и овеществление прочитывается 
буквально, односторонне - как господство объективирующей и квантифицирующей рационализации.

Вернемся теперь к общественному мнению. Дело не только в том, что его фиксируют, считают и тем самым конструируют. Дело не в меньшей мере в том, что речь идет именно о «мнении», в том, что общество рассматривается в демократическом капитализме не только как объект управления, но и как совокупность мнений, образующая коллективного субъекта, пусть пассивного (подобно привязанному к мачте Одиссею), но тем не менее обладающего свободой оценки и позиционирования. Когда Адорно размышляет об общественном мнении, он критикует его именно по этой линии, а вовсе не по более очевидной линии превращения людей в вещи и цифры (Adorno, 2005). Опредмечивание действует диалектически: объективирующее и механизирующее отчуждение работает только через посредство якобы автономных изолированных субъектов. При этом происходит что-то вроде диалектического синтеза, потому что отделенный от объективности «свободный» субъект мнения сам становится подозрительно похож на автомат (то есть механизированный объект): вся его свобода сводится к «да», «нет», «скорее да», «скорее нет» и «не знаю».

В своем эссе «Исследования общественного мнения и публичность» Адорно пишет: «Исследование общественного мнения совершает попытку, абстрактную и изолированную, изолировать в свою очередь, то есть выделить, сугубо субъективный момент индивидуального мнения и выдать этот феномен, который на деле является неприкрытым отражением социальной объективности, с ее юридической структурой, за основу социальной реальности» (Adorno, 2005: 123). При этом «публичность», сведенная к технологии, не предоставляя возможности реального общения, оборачивается чисто созерцательной установкой пассивной «публики»: «Народ был глубоко пассивной, воображаемой аудиторией машины общественного мнения, которая сообщала ему объективно наиболее важные, политические новости, примерно так же, как аудитория театра, которая требует ее развлекать. А теперь он стал придатком этой машины» (Ibid.: 121). И: «Право людей на публичность превратилось в распределяемую им дозу публичности: там, где они должны были быть ее субъектами, они превратились в ее объекты» (Ibid.).

В совокупности получается, что опросы общественного мнения одновременно выполняют две противоположных операции. Они одной рукой полагают общество как набор субъектов, якобы свободно формирующих просвещенное мнение, которое должно учитывать демократическое правительство, а другой рукой реифицируют это мнение, превращают его в объект тестового измерения (по-французски «зондаж»), в логике физически понимаемой «природы», черного ящика, о котором мы получаем извне те или иные достоверные, но заранее неизвестные, сведения.

Примерно так же устроены современные выборы. Выборы трактуют волю народа как такой черный ящик, чтобы познать который, необходимо каждый раз проводить эксперимент. Но выборы, как я уже отметил, все же направлены на выявление конкретной воли народа, он выступает не столько как предмет, сколько 
как оракул (vox populi vox dei). А опросы научно опредмечивают этот оракул и воспринимают его как набор уже сформированных, наблюдаемых свойств-мнений. Начиная с позднего Средневековья, народ на Западе понимается как воплощение Бога (Канторович, 2013), как высшая инстанция легитимности, которая не отдает прямых приказов (как в общем-то и сам Бог) лишь в силу своего слишком большого размера. В эпоху Ренессанса примерно так же начинает пониматься и природа в целом, поэтому наука Нового времени делает двойной ход: подчиняет и объективирует (представляет) природу, но в то же время представительствует ей, говорит от лица ее высшей истины. Сдвиг от изучения природы к изучению «публики», которая в буквальном смысле что-то говорит, лишь усилил этот двойной эффект - но не надо забывать, и Юдин со своими двумя публичными мнениями (буржуазным и демократическим) это подчеркивает, что «публика» - это некая просвещенная и просвеченная версия старого «народа» (publicum от populus), потому она все время и норовит скатиться к «популизму». В ней остается какая-то загадка.

Получается, что сущность опросов общественного мнения двойственна и противоречива. Эти опросы - нервный узел, симптом капиталистической демократии. Они воплощают в себе диалектический синтез (в плохом смысле) ее противоречий, объективизируя ее субъективизированное (тогда как выборы, наоборот, субъективизируют объективизированное). При этом подобное отрицание отрицания не работает как обратная операция, то есть объективация отнюдь не снимает проблемы, заложенной в субъективации, а усугубляет ее. Субъективное мнение не становится благодаря измерению более осмысленным или лучше увязанным с глубинным ходом истории, потому что оно фиксируется на том же поверхностном уровне, где вырабатывается, без осознания своей классовой, функциональной природы и тех проблем, в ответ на которые оно возникает. Овеществление производится по тем же законам, что и овеществление природы, которое как раз производится от лица субъекта, и таким образом сохраняется позиция абсолютной субъективности, незаинтересованного взгляда, который лишь перемещается в фигуру самого полстера и его заказчика. Тем не менее благодаря синтетической форме операции опросы общественного мнения создают видимость истины, видимость того, что объективация устраняет односторонность субъективации, и мы видим общество таким, каково оно на самом деле.

У Лукача, когда он критикует распад буржуазного общества на созерцательного субъекта и порабощенный объект, тоже есть точка диалектического синтеза, которую автор «Истории и классового сознания» считает истинной, настоящей. Это у него пролетариат - объект, который обнаруживает собственную субъективность и восстает. Так получается потому, что в этой точке субъект-объект чувствует и осознает негативность системы, невозможность своей позиции, и его субъективация означает волю выпрыгнуть из системы. Ничего подобного обычно не происходит при выборах (кроме протестных) и никогда не происходит при опросах общественного мнения (кроме случаев отказа отвечать на дурацкие 
вопросы), поэтому они несут в себе только видимость синтеза, или частичный синтез. Если же «опросить» пролетариат (как это сегодня обычно и делается), то возникает ложь, потому что человек, во-первых, сведенный в своей деятельности к инструменту и испытывающий фрустрацию по этому поводу, ставится в положение буржуа, который может академично и толерантно высказывать «мнения» по различным вопросам, в которых ничего особенно не понимает. В лучшем случае пролетарий использует этот опрос для выражения своего негативизма, но и тогда мы не особенно продвинемся в истинном понимании ситуации (так как подлинная интрига заключается тут в отношении, в которое с этим пролетарием вступают буржуазный эксперт и полупролетаризированный интервьюер).

Впрочем, наличие в России такой «сильной» трактовки опросов, как социология Левада-Центра, делает симптоматику пусть не снятой, но более заметной, чем обычно: по крайней мере, здесь показывается, что предельное овеществление объекта исследования делает последний почти неспособным к каким-либо мнениям вообще, результат противоречит процедуре, и абстрактно-наукообразное прочтение сложного общества верно высвечивает негативность ситуации. Эта негативность, как известно, приписывается «идентичности» информантов (Гудков, 2004), но на самом деле заложена, хотя и в меньшей степени, в самой процедуре опроса, и в самой позиции социолога-эксперта. Вообще говоря, по Гегелю (Гегель, 1997), любая идентичность негативна по определению, поэтому неудивительно, что отрицательное выходит наружу под идентифицирующим, отождествляющим взглядом абстрактной рациональности.

Диалектика субъективности и объективности, о которой идет речь, имеет не только структурный, но и исторический смысл. Юдин в своей книге упоминает, что «мнение» ранее было термином, подчиненным «знанию» и рассматривалось скорее пренебрежительно (с. 35). Выдвижение в XVIII веке «публичного мнения» на роль альтернативной ценности, своего рода нового духа государств, было новацией, оправдывавшей процесс, который мы сегодня назвали бы демократизацией. Общественное мнение формировало множественные, негосударственные центры власти. В своей книге «Демократия, или Демон и Гегемон» (Магун, 2016; та же серия «Азбука понятий», что у книги Юдина) я писал, что почти все основные исторические понятия переживают в период XVIII-XIX веков переворачивание, инверсию прежнего значения. Так, например, «демократия» ранее считалась одним из худших режимов и противопоставлялась умеренному сдержанному правлению, а потом стала синонимом лучшего режима и официальным названием смешанного правления. Точно так же и «общественное мнение» содержит в себе переворачивание традиционных метафизических иерархий (где начиная с Платона «докса», мнение, противостоит «эпистеме», знанию), хотя инверсия не будет полной: «докса» была уже к этому времени переоценена в рамках теологии (православие: орте докса). Тем не менее ясно, что общественное мнение - результат инверсии понятий, которая выдвигала подчиненную сферу «публичности» (она же профанность), с ее «мнениями», на роль судебной и критической инстанции. Мнение по 
определению произвольно и несет в себе момент безответственности: может быть так, а может и эдак, поэтому иногда говорят о «досужем мнении». Кроме того, «мнения», изучаемые опросами, в то же время являются свернутыми аффектами: это не только оценки фактов, но также ценности и установки, хотя на уровне общества они предстают как снизу идущие и непроясненные устремления.

Мнение предполагает случайного эмпирического субъекта, который произвольно решает, что хорошо и что плохо. Но поскольку подсчет мнений уже не субъективен, а объективен, и поскольку речь идет не о пламенном подрыве государства, а о вписывании субъекта в своего рода реестр возможных мнений, энциклопедию государства, постольку мы возвращаемся от доксы к эпистеме, новой эпистеме доксы, истине неистинного существования, предопределенности произвола.

За что критиковать этот новый синтетический порядок? Юдин показывает, что он авторитарен (плебисцитарное правление элит) и неистинен (люди высказывают не-свои мнения, а распределяются по определенным государством ячейкам). Но в то же время он по-своему объективен, рационален и свободен (у людей есть все-таки право выбора из имеющихся альтернатив). Поэтому он может поворачиваться к нам разными своими гранями. Что несет режим, основанный на общественном мнении, на Западе, где он основан на честных выборах? Он несет в себе прежде всего власть чередования, дизъюнктивного синтеза, где политика объективно детерминирована вплоть до взаимно дополнительных альтернатив, и индивид зажат в тиски энциклопедии, анкеты, где вопросы задает не он. Но произвол власть имущих здесь минимален.

А что несет такой режим в нелиберальных государствах вроде России, где он, по сути, заменяет собой выборы? Тут он авторитарен, то есть в гораздо большей степени субъективен, чем на Западе. Темной массой правят вожди-манипуляторы, объективируя ее, но воплощая своим поведением тот произвол, который заложен в идее «мнения». Содержанием политики становится национализм - тревога за коллективное «Я», за поддержание своей субъектности, в обществе, где содержание внутренней политики все равно на 9о\% подчиняется объективной логике международных норм. И эта тревога идентичности, испытываемая лидерами, как бы делегируется ими вниз, «общественному мнению», предоставляя им алиби и предоставляя им возможность сохранять рациональную объективность поведения. Мы имеем классическую ситуацию, описанную психоанализом на материале индивидуальности: субъект расщеплен и переживает свою собственную волю как якобы объективно-материальные, «бессознательные» аффекты. То же в нашем случае происходит со всей страной: внешне спокойный и тактически рациональный «вождь» ведет гиперэмоциональную политику, ссылаясь на рессентимент общества, подпитку которого через СМИ организует сам ${ }^{4}$.

4. См. подробнее об этом в: Magun, 2016. 
Подведем итог. Книга Юдина является и историко-понятийным, и критическиполемическим текстом. Обе эти свои задачи она решает отлично. Но что делать? Книга в конце дает несколько альтернативных сценариев, не все из которых автор одинаково поддерживает. Например, очевидно, что проект Дж. Фишкина об институционализации дискуссий вместо тупого индивидуального голосования (фактически институционализация фокус-групп) (Fishkin, 1991) очень привлекателен - но у кого будет политическая воля его реализовать? Возможно, у потенциальной новой власти, которая когда-нибудь возникнет в России и захочет отменить плебисцитарные выборы и опросы. При этом в краткой перспективе, несмотря на всю критику, книга не призывает отменить опросы общественного мнения - скорее поставить их на свое место. Хотя с пафосом критики я в целом согласен, местами хочется даже защитить полстеров от автора.

Во-первых, все-таки гораздо лучше, что они есть, чем если бы их, в нашей политической констелляции, не было - то есть власть имущие вообще не интересовались бы установками населения (вспомним поздний Советский Союз, который действительно пострадал от отсутствия соцопросов, и отсюда особая роль опросов в современной РФ). Опросы - своеобразная дань олигархического капитализма демократии. Аналогичным образом современная естественная наука, при всем ее наивном догматизме, все-таки лучше отражает природу, чем чисто умозрительная средневековая физика.

Во-вторых, карикатурно-типизирующая картина «мнений» в известной степени совпадает с карикатурными же представлениями о себе самих граждан. Тот же Адорно, как известно, в 1940-1950-х годах участвовал в эмпирическом исследовании «авторитарной личности» в США (Адорно, 2001), которое вообще-то по своей разоблачительной установке в отношении обывателей было вполне в духе ЛевадаЦентра и в свое время стало мишенью яростной критики: критики, граничащей с аллергической реакцией на приход чужака, да еще левого идеолога, в «объективную» эмпирическую науку ${ }^{5}$. Но, в отличие от Левада-Центра, Адорно придает своим результатам диалектическую трактовку. Он говорит, что эмпирическая классификация всяких неприятных типов личности, которую они дают, работает только при условии самотипизации, которую проводят над собой сами испытуемые! И высшей точкой исследования для него является поиск «нетипизируемых» людей, тех, кто не вписывается в стереотипные категории. Вот этой позитивной задачи не хватает негативной социологии, даже столь экспериментальной, как у Левада-Центра.

В-третьих, полстеры все-таки используют в своей деятельности не только индивидуальное анкетирование, но и фокус-группы. Это «качественный», понимающий инструмент, который гомологичен не выборам, а демократическим экспериментам типа Фишкина (Юдин относится к фокус-группам скептически, но, похоже, не к идее, а к их реальному бытованию).

5. Г. Шарафутдинова верно упоминает это исследование Адорно как один из источников вдохновения для теории Левады и Сo: Sharafutdinova, 2019: 176. 
В-четвертых, Юдин почти не упоминает о современных методах статистической обработки опросов. Хотя люди опрашиваются индивидуально, данные математически обрабатываются так, чтобы можно было сделать вывод о влиянии социальных характеристик людей на их ответы. Через регрессионные модели, отражающие влияние на ответы людей их различных групповых идентичностей, исследователь может увидеть макроструктуру общества. Поэтому, хотя на «входе» мы имеем абстрактно-агрегативную модель, на «выходе» мы получаем, если не классы, то некоторые объективные структуры, которые социальные аналитики ставят в соответствие реальным социально-экономическим условиям жизни людей. Пусть это и не классовый анализ в марксистском духе (класс может существовать» «в себе» и в мнениях не проявляться, его как раз стоило бы изучать «левадовскими» методами провокации и выявления ЗБР), но нечто направленное в ту же сторону.

То есть социологи опросов, в тех частых случаях, когда они не только технологи, но и ученые, стараются изнутри преодолеть ограничения своего метода. Но познание действительности как она есть требует, чтобы они включали в познание критический самоанализ своего собственного исследовательского взгляда как социального факта. А это автоматически привело бы к анализу «общественного мнения» как внутренне расколотого: между фактом и ценностью, между сущим и потенциальным, между сознательным и бессознательным, а попросту говоря, между просвещенным и непросвещенным. Для того чтобы вскрыть этот разрыв, необходима социальная наука диалектического типа.

\section{Литература}

Адорно Т. (2001). Исследование авторитарной личности. М.: Серебряные нити.

Адорно Т., Хоркхаймер М. (1997). Диалектика Просвещения: философские фрагменты / Пер. с нем. М. Кузнецова. М., СПб.: Медиум, Ювента.

Велехов Л., Гудков Л. (2016). Лев Гудков: «Это катастрофа. Но медленная». URL: https://www.svoboda.org/a/28005133.html (дата доступа: 12.09.2020).

Выготский Л. (1984). Проблема возраста // Выготский Л. Собрание сочинений. Т. 4. М.: Педагогика. С. 244-269.

Гегель Г. В. Ф. (1997). Наука Логики. Книга 1. СПб: Наука.

Гудков Л. (2004). Негативная идентичность. М.: Новое литературное обозрение.

Гудков Л. (2020). Представления о политической системе. URL: https://www.levada. ru/2020/o9/o8/predstavleniya-o-politicheskoj-sisteme/ (дата доступа: 20.09.2020).

Канторович Э. Х. (2015). Два тела короля / Пер. с англ. М. А. Бойцова и А. Ю. Серегиной. М.: Изд-во ин-та Гайдара.

Левада Ю. А. (ред.). (1993). Советский простой человек: опыт социального портрета на рубеже 9о-х. М.: Мировой океан.

Лукач Г. (2003). История и классовое сознание / Пер. с нем. С. Земляного. М.: Логос-Альтера. 
Магун А. (2016). Демократия: Демон и Гегемон. СПб: ЕУ СПб.

Маркузе Г. (1994). Одномерный человек / Пер. с англ. А. Юдина, Ю. Данько, А. Жаровского. M.: REFL-book.

Юдин Г. (2019). Десять тезисов о любви к Сталину. URL: https:/echo.msk.ru/blog/ grishayudin/2410897-еcho/ (дата доступа: 12.09.2020).

Adorno Th. W. (2005). Opinion Research and Publicness / Transl. by A. J. Perrin, L. Jarkko // Sociological Theory. Vol. 23. № 1. P. 116-123.

Fishkin J. (1991). Democracy and Deliberation: New Directions for Democratic Reform. New Haven: Yale University Press.

Honneth A. (2012). Reification: A New Look at the Old Idea. Oxford: Oxford University Press.

Magun A. (2016). Hysterical Machiavellianism: Russian Foreign Policy and the International Non-Relation // Theory and Event. Vol. 19. № 3.

Sharafutdinova G. (2019). Was There a «Simple Soviet» Person? Debating the Politics and Sociology of «Homo Sovieticus» // Slavic Review. Vol. 78. № 1. P. 173-195.

\title{
The Probing of God-Bearer
}

\author{
Artemy Magun \\ Professor, Director of the Stasis Center for Practical Philosophy, European University at Saint-Petersburg \\ Address: 6/1A Gagarinskaya Street, 191187 St. Petersburg \\ E-mail: amagun@eu.spb.ru
}

The article is simultaneously an extended review of the book by Grigory Yudin entitled Public Opinion; or, The Power of Numbers (EUSPb Press, 2020) and an essay on the phenomenon of public opinion in the light of the repressive tendencies of contemporary society from the standpoint of critical theory. Relying mostly on Adorno, the author shows that public opinion polls are not only the result of the alienating reification, but also an effect of the basic subjectivism which turns the relationship between the subject and society into a detached, contemplative, and judgmental attitude. The objectivization coincides with subjectivization. Thus, in accordance with Yudin's book, social science, if it wants to be more than an instrument of bureaucratic domination, has to rely on dialectical logic.

Keywords: public opinion, Levada Center, critical theory, dialectic in sociology, Grigory Yudin, quantification, reification.

\section{References}

Adorno T. W. (2001) Issledovanie avtoritarnoj lichnosti [The Authoritarian Personality], Moscow: Serebrjanye niti.

Adorno Th. W. (2005) Opinion Research and Publicness. Sociological Theory, vol. 23, no 1, pp. 116-123.

Adorno T. W., Horkheimer M. (1997) Dialektika Prosveshhenija: filosofskie fragmenty [Dialectic of Enlightenment: Philosophical Fragments], Moscow: Medium, Yuventa.

Fishkin J. (1991) Democracy and Deliberation: New Directions for Democratic Reform, New Haven: Yale University Press. 
Gudkov L. (2004) Negativnaja identichnost' [Negative Identity], Moscow: New Literary Pbserver.

Gudkov L. (2020) Predstavlenija o politicheskoj sisteme [Views of the Political System]. Available at: https://www.levada.ru/2020/o9/o8/predstavleniya-o-politicheskoj-sisteme/ (accessed 20 September 2020).

Hegel G. W. F. (1997) Nauka Logiki. Kniga 1 [Science of Logic, Book 1], Saint Petersburg: Nauka. Honneth A. (2012) Reification: A New Look at the Old Idea, Oxford: Oxford University Press.

Kantorowicz E. (2013) Dva tela korolja [The King's Two Bodies], Moscow: Gaidar Institute Press.

Levada Y. (ed.) (1993) Sovetskij prostoj chelovek: opyt social'nogo portreta na rubezhe 9o- $h$ [Soviet Simple Man: An Attempt of the Social Portrait at the Turn of the 1990s], Moscow: Mirovoy okean.

Magun A. (2016) Demokratija: Demon i Gegemon [Democracy: Demon and Hegemon], Saint Petersburg: EU Press.

Magun A. (2016) Hysterical Machiavellianism: Russian Foreign Policy and the International NonRelation. Theory and Event, vol. 19, no 3.

Marcuse G. (1994) Odnomernyj chelovek [One-Dimensional Man], Moscow: REFL-book.

Sharafutdinova G. (2019) Was There a "Simple Soviet" Person? Debating the Politics and Sociology of "Homo Sovieticus". Slavic Review, vol. 78, no 1, pp. 173-195.

Velekhov L., Gunkov L. (2016) Lev Gudkov: "Jeto katastrofa. No medlennaja" [Lev Gudkov: "This is a Disaster. But Slow-Moving"]. Available at: https://www.svoboda.org/a/28005133.html (accessed 12 September 2020).

Vygotsky L. (1984) Problema vozrasta [Age Problem]. Sobranie sochinenij. T. 4 [Collected Works, Vol. 4], Moscow: Pedagogika, pp. 244-269.

Yudin G. (2019) Desjat' tezisov o ljubvi k Stalinu [Ten Theses on the Love of Stalin]. Available at: https://echo.msk.ru/blog/grishayudin/2410897-echo/ (accessed 12 September 2020). 